\title{
Olga Czerniawska
}

Akademia Humanistyczno - Ekonomiczna w Łodzi

Emerytowany profesor Uniwersytetu Łódzkiego

\section{Edukacja dorosłych we Włoszech na przełomie XX i XXI wieku}

\author{
Adult Education in Italy at the turn of XX and XXI century
}

Streszczenie. Włochy wśród państw rozwiniętych, mają jeden z najniższych poziomów wykształcenia ludności. Po II wojnie światowej rząd prowadził walkę z analfabetyzmem, który był powszechny szczególnie na południu kraju i na wyspach. Edukacja dorosłych obejmuje tzw. grupy priorytetowe. Obok młodocianych są to więźniowie i obcokrajowcy. Jednak podjęcie decyzji o uczeniu się w instytucjach nie jest łatwe. W wielu przypadkach rozpoczęciu edukacji towarzyszą oczekiwania lepszej pozycji zawodowej i społecznej, lepszych zarobków. Pozostaje również pytanie (niepewność) kiedy zacząć? Gdzie zacząć? Czego się uczyć? Obecnie prowadzi się we Włoszech dyskusję na temat integracji systemów edukacji dorosłych. Konieczne jest opracowanie programu zintegrowanego, obejmującego różne grupy: o wysokim poziomie wykształcenia, dobrze przygotowane do edukacji ustawicznej (w tym przez Internet), o niskim poziomie wykształcenia, które (mimo to) radzą sobie z wyborem ofert edukacyjnych oraz najsłabszą - wymagającą wsparcia i pomocy w wyborze kursów, szkoleń i w ich kontynuacji. Edukację dorosłych we Włoszech cechuje indywidualne podejście do jej uczestników, można mówić o edukacji przez ugodę i wybór. Podstawą działania jest jednostka wraz z jej problemami, potrzebami, oczekiwaniami i zainteresowaniami. Badania nad edukacją ujawniają rolę grup skupiających jednostki o podobnych zainteresowaniach, potrzebach i umiejętnościach. Owe grupy stają się bazą dla opracowania projektów działań edukacyjnych i programów pracy. Instytucje edukacji dorosłych to głównie Centra Edukacji Permanentnej (Centro educazione permanente) w poszczególnych miejscowościach. Ważną rolę odgrywają również Prowincjonalne Centra Edukacji Dorosłych (Centri Provinciali per L'Istruzione degli Adulti), Uniwersytety Trzeciego Wieku oraz biblioteki.

Słowa kluczowe: edukacja dorosłych we Włoszech, edukacja emigrantów we Włoszech.

Summary. Italy among developed countries, has one of the lowest levels of education of the population. After World War II the government led the fight against illiteracy, which 
was common especially in the south and on the islands. Adult education includes the socalled priority groups. In addition to juvenile there are prisoners and foreigners. However, the decision about learning in institutions is not easy. In many cases, the start of education is accompanied by expectations of better professional and social position, better pay. There also remains a question (uncertainty) when to start ?, where to start?, what to learn? Currently in Italy is conducted a discussion on the integration of adult education. It is necessary to develop an integrated program covering different groups: a high level of education, well prepared for lifelong learning (including the Internet), a low level of education, which (despite a) deal with the choice of learning opportunities and the weakest - requiring support and assistance in the choice of courses, training and in their follow-up. Adult Education in Italy is characterized by an individual approach to its participants can talk about education through settlement and choice. The base of the action is unit with its problems, needs, expectations and interests. Research on education reveal the role of groups involving individuals with similar interests, needs and abilities. These groups become the basis for the development of educational projects and programs of work. Adult education institutions are mainly Permanent Education Centres (Centro educazione permanente) in different localities. An important role is played by the Provincial Adult Education Centres (Centri Provinciali per L'Istruzione degli Adulti), Universities of the Third Age and the library.

Keywords: adult education in Italy, the education of immigrants in Italy.

\section{Uwagi wstępne}

$\mathrm{Na}$ temat edukacji dorosłych we Włoszech pisałam wielokrotnie. Tę wypowiedź traktuję jako chyba ostatnią. Nie jest łatwo pisać na ten temat, brakuje materiałów. Nie zwiedzam instytucji edukacyjnych. Moja wiedza opiera się na hospitowanych instytucjach w latach 80-tych ubiegłego wieku, na analizie czasopism z zakresu edukacji dorosłych, ostatniego pisma Adultita, które przestało wychodzić w 2008 roku i działał w nim znany w Polsce Ettore Gelpi, któremu poświęcony był po jego śmierci w 2002 roku dział „Z działalności instytucji edukacji dorosłych". W tym dziale zamieszczane były artykuły dotyczące edukacji cudzoziemców, kobiet i UTW oraz uczestników edukacji dorosłych. Źródłem informacji są także wydawnictwa z 2010 roku poświęcone edukacji dorosłych w Europie i we Włoszech.

Pewne informacje, ale bardzo oszczędne, zawiera sprawozdanie z Międzynarodowej VI Konferencji Edukacji Dorosłych w Balen w Brazylii (2008 r. „Życie”). Niskie wskaźniki uczestnictwa Włochów w instytucjach edukacji dorosłych, niski poziom wykształcenia formalnego dorosłych. Te „twarde" dane w moim odczuciu nie oddają żywotności włoskiego społeczeństwa, które jest otwarte w kontaktach społecznych, pełne inicjatywy, otwarte na 
innych, grzeczne, obdarzone wysoką kulturą dnia codziennego. Małe miasteczka są bardzo aktywne, pełne restauracji, barów, sklepów, różnego rodzaju form aktywności, w tym UTW.

Noszę w sobie dwa obrazy Italii: barwny, żywotny, aktywnego społeczeństwa otwartego, przyjaznego, wielobarwnego przez emigrantów od czarnoskórych, Sudańczyków, Arabów, Chińczyków, Filipińczyków, Erytrejczyków. Spotkać ich można w Rzymie i w małych miastach, w kościołach, na lotnisku jako obsługę, na placach i targowiskach jako sprzedawców. Są częściowo wrośnięci w społeczność lokalną, ale drugie pokolenie emigrantów nie jest zintegrowane ze społeczeństwem włoskim.

\section{System edukacji we Włoszech}

Pisząc o edukacji dorosłych, koniecznym wydaje się przedstawić system edukacji dla młodzieży, bowiem edukacja dorosłych jest drugą szansą edukacyjną, jaką więc jest szansa pierwsza, podstawowa?

W 2003 roku we Włoszech weszła w życie nowa ustawa zwana reformą Maratti. Przewiduje ona obowiązek szkolny najmniej 12 lat do 18-go roku życia, ale do uzyskania tytułu zawodowego. Głównym celem reformy jest zbliżenie szkolnictwa do świata pracy, dostosowanie programów do potrzeb ucznia, przejście na system kredytów, wybór systemu kształcenia, który pozwala uczniowi w fazie między zakończeniem edukacji a podjęciem pracy.

Nowy system powołał przedszkole trzyletnie, które nie jest obowiązkowe. Jest to swoista pomoc dla rodziców. Pierwszy obowiązek szkolny pojawia się dla dzieci, które ukończyły 6 lat i składa się ze szkoły podstawowej - scuola primaria - która trwa 5 lat i gimnazjum (scuola secondaria di primo grado) trwające trzy lata. Ośmioletni cykl kształcenia jest bezpłatny i obowiązkowy. Wniosek do szkoły wypełniają rodzice i piszą, czy chcą aby dziecko chodziło na religię, korzystało ze stołówki i świetlicy oraz autobusu. Określają, ile czasu będzie chodziło do szkoły; 30 godzin jest obowiązkowe. Do gimnazjum przechodzi się automatycznie. Nauka w nim trwa trzy lata i kończy pierwszy cykl edukacji; trzeci rok podsumowuje naukę, musi ona trwać 27 godzin tygodniowo. Po ośmioletniej nauce uczeń zdaje egzamin podstawowy.

Uczeń, zwykle 14-letni, dokonuje wyboru między pięcioletnim liceum o następujących profilach: klasycznym, nauk ścisłych, językowym, ekonomicznym, technicznym lub artystycznym. Te typy liceum dają przygotowanie zawodowe połączone z praktyką. Trwają one 5 lat i składają się z dwóch 
cykli nauki i roku praktyki. Można po nim studiować. Inny typ szkoły to szkoła przygotowująca do zawodu, trwa 4 lata. Każdy ma prawo podjęcia dodatkowego roku przygotowującego do matury (2006, Przewodnik).

Uczeń, który otrzyma ocenę niedostateczną ma możliwość otrzymać kredyt - wirtualną ocenę dostateczną, którą musi poprawić w następnym roku. Jeśli jej nie poprawi, nie otrzymuje promocji. Uczniowie uczestniczą w dodatkowych zajęciach. System kredytów i przedmiotów obowiązujących i do wyboru to nowość we włoskim systemie edukacji.

\section{Edukacja emigrantów}

Do edukacji mają także prawo cudzoziemcy. Młodocianych zapisują rodzice. Jeśli chodzili do szkoły, uwzględnia się świadectwo, program i klasę. Muszą mieć także zaświadczenie o szczepieniach. Ważną rolę w zapisie do szkoły i do klasy spełnia mediator kulturalny, pomagający w nauce języka włoskiego.

Dorośli cudzoziemcy także mogą uczyć się na wszystkich szczeblach, jeśli nie mają świadectwa uczenia się dwunastu lat. Tak jest w niektórych krajach Ameryki Łacińskiej, muszą uzupełniać szkołę dwunastu lat. Mogą korzystać z biur pracy (centro per l'impiego). Muszą dostarczyć dyplom przetłumaczony na język włoski. W Centri territoriali permanenti EDA i Corsi serali Della Secondaria Superiore można uzupełnić poziom wykształcenia lub podjąć naukę w szkole. Wykształcenie zawodowe można zdobyć w systemie kształcenia zawodowego, a rozwój w zakresie kultury oferują różne kursy w trzecim sektorze, kurs czasu wolnego oraz stowarzyszenia kulturalne, polityczne, religijne w wolny rynek.

Czy istniejący system edukacji dorosłych jest wystarczający? Potrzeby społeczne są bardzo zróżnicowane. Każda grupa potencjalnych uczestników ma inne potrzeby i oczekiwania. Emigranci są bardzo zróżnicowani - od analfabetów o niskim poziomie edukacji, po osoby wykształcone i uczonych, ale także inne potrzeby mają kobiety, mężczyźni i młodociani, w tym ci z niepowodzeniami szkolnymi w kraju pochodzenia i włoskim systemie edukacyjnym, bezrobotni długoterminowi i krótkoterminowi, w tym kobiety i mężczyźni, osoby w wieku 50+, czyli starsze. Odrębna grupa to młodociani w wieku 15-29 lat. 


\section{Zróżnicowane uczestników edukacji dorosłych}

We włoskiej populacji dorosłych można wyróżnić trzy grupy potencjalnych uczestników instytucji edukacyjnych. Grupa pierwsza to osoby o wysokim poziomie kulturalnym, wykształcone i aktywne społecznie, które mogą być świadomymi i samodzielnymi uczestnikami edukacji formalnej.

Druga - to dorośli i młodociani, którzy mają trudności w procesie uczenia się i braki w edukacji, ale wspomagane mogą się uczyć.

Trzecia - to osoby, które miały i mają trudności w uczestniczeniu w instytucjach edukacyjnych. Ta grupa wymaga specjalnych starań, wsparcia, programów i instytucji (Il lifelong learning, 2010).

Wskaźniki uczestnictwa w edukacji dorosłych poszczególnych grup dla Włoch i Unii Europejskiej są następujące:

- najniższy poziom wykształcenia u 37,1\% populacji, gdy w Unii Europejskiej procent ten wynosi 25 do 19,5

- $17 \%$ pracujących we Włoszech ma wystarczające wykształcenie, w Unii Europejskiej 32\%. Włochy mają wyraźny deficyt wykształconych kadr pracujących. Źle wykształcona jest populacja młodych dorosłych 20-34-letnich, oraz obcokrajowcy przybywający do Włoch bez znajomości języka (2008 Appunto sulle Formazione). Na 36 milionów dorosłych obywateli (20-64 lat), 16 milionów ma niższe wykształcenie od wymaganych ustawowo 8 lat. Następna grupa 3 milionów (20-34 lata) też ma niskie wykształcenie. Około dwieście sześćdziesiąt tysięcy nie ma pracy. Państwo i władze regionalne starają się stworzyć sieć instytucji edukacyjnych, uzupełniających wykształcenie i dających kwalifikacje zawodowe. W latach 2011-2013 ma się kształcić trzysta tysięcy młodych dorosłych za 1000 euro na jednego uczącego się. Przewiduje się kształcenie 3 milionów młodych ludzi, po 2 miliony w przeciągu 9 lat. Przewiduje się objęcie edukacją od 200 do 300 tysięcy rocznie. Młodzi dorośli bez kwalifikacji, pracujący, powinni uczyć się 60 godzin rocznie. Bezrobotni powinni być objęci stażami i kursami zawodowymi. Obcokrajowcy powinni uczyć się języka, wiedzy społeczno-obywatelskiej o instytucjach we Włoszech.

Kursy w tym zakresie nie mogą być krótsze niż 10 godzin. Bezpłatne kursy zawodowe i społeczno-językowe dla młodocianych i obcokrajowców powinny być organizowane przez władze regionalne w całym kraju.

Badania poziomu wykształcenia we Włoszech wykazały, że populacja dorosłych 25-65 lat ma bardzo niski poziom wykształcenia formalnego 
i jest na granicy analfabetyzmu. Najmłodsza emigracja ma bardzo niski poziom wykształcenia. W zasadzie $2 / 3$ populacji znajduje się w sytuacji ryzyka analfabetyzmu. Osoby ze szkołą podstawową mają słabe kompetencje, podobnie ze szkołą średnią. Dobre kompetencje mają osoby po liceum.

\section{Centro educazione permanente}

Instytucje edukacji dorosłych to głównie centra edukacji ustawicznej w poszczególnych miejscowościach. Działają przy lub też w szkołach powszechnych i zawodowych, w technikach. Ich zajęcia obejmują podstawowe przedmioty, język włoski, język obcy, historię, nauki przyrodnicze i zajęcia techniczne. Pracuje w nich około pięciu nauczycieli. Niektóre centra działają przy szkołach zawodowych, technicznych i artystycznych. Kończą się dyplomem zawodowym. Inne prowadzą kursy wieczorowe i te działają w szkołach wyższych.

Włochy, jako państwo rozwinięte, znajdują się wśród krajów o niskim poziomie wykształcenia ludności. Po II wojnie światowej prowadziły walkę z analfabetyzmem, który był powszechny szczególnie na południu i na wyspach (1996, Czerniawska). Wieloletnia walka z analfabetyzmem literalnych, z brakiem świadectwa ukończenia szkoły podstawowej i średniej. 16 milionów osób dorosłych w wieku 25-64 lat ma zaledwie ukończone szkoły elementarne - 48\%. (2010, Quadermo nr 9). Jedna trzecia populacji jest na granicy analfabetyzmu. Jedna trzecia osiągnęła słabą umiejętność czytania. Pozostali mają wyższy poziom, ale określa się ich jako młodocianych trudnych, izolujących się, nie patriotycznych, biernych, napotykających bardzo często niepowodzenia szkolne. Także starsi emigranci nie są na tyle zintegrowani, żeby włączać się w działalność UTW, które są we Włoszech dostępne i rozwijają się dynamicznie.

Edukację dorosłych we Włoszech cechuje indywidualne podejście do uczestników, można mówić o edukacji przez ugodę i wybór. „Uczenie się w dorosłości powstaje w oparciu o doświadczenia życiowe, pracę, trudności, konflikty, przemiany, ale także zainteresowania, inspiracje i potrzeby osoby dorosłej. Towarzyszą temu wybory i decyzje które powodują określone zachowania". (2010, Quadermo nr 9 s. 93).

Podjęcie decyzji uczenia się w instytucjach nie jest łatwe, od nieuczenia się do uczenia się prowadzi długa droga, jest to proces bardzo złożony. Można uczyć się, aby uczyć się świadomie, refleksyjnie. Uczenie się powoduje zmiany, rozwój, ale i zmiany także powstają przed decyzją uczenia się. 
W wielu przypadkach podejmowaniu uczenia się towarzyszą oczekiwania lepszej pozycji zawodowej i społecznej, lepszych zarobków, wzmocnienie pozycji w społeczności lokalnej. Pozostaje zawsze pytanie i niepewność kiedy zacząć, gdzie zacząć, czego się uczyć.

Program edukacji dorosłych we Włoszech adresowany jest do populacji od 25-64 lat. W 2006 roku 6,2\% populacji kształciło się, gdy w Unii Europejskiej procent ten wynosił 13 do 15 .

\section{Centri Provinciali per L'Istruzione degli Adulti}

Dlatego podstawowe instytucje edukacji dorosłych, finansowane przez samorząd i państwo, są Centri Territoriali Permanenti per l'Educazione degli adulti (CTP). Funkcjonują przy szkołach elementarnych i innych. W 2007 roku było ich pięćset dwadzieścia dwa z trzystu szesnastoma tysiącami sześciuset siedemnastoma uczestnikami. Corsi seriali działały przy szkołach wyższych; w 2007 roku było osiemset trzydzieści sześć z sześćdziesięcioma sześcioma tysiącami pięćset czterdziestoma pięcioma uczestnikami. W latach 2008-2009 uczyło się 2,5\% osób populacji, której brakowało świadectwa szkoły elementarnej i średniej. W kursach języka włoskiego i integracji uczestniczyli obcokrajowcy. W kursach, trwających od 40 do 100 godzin, uczono języka, informatyki, a także tematów: artystycznych, poradnictwa, bezpieczeństwa i innych wybranych przez uczestników. W 2008 roku działały we Włoszech pięćset trzydzieści dwa CTP: dwieście dwanaście na Północy, dziewięćdziesiąt cztery w Centrum, dwieście dwadzieścia sześć na Południu i wyspach. 57\% programów dotyczyło alfabetyzacji funkcjonalnej (corsi brevi modulari). Uczestnicy kursów to osoby od 16 lat - młodociani - do 35 lat. W większości kobiety (58\%) i obcokrajowcy (41\%).

Osobne centra działają we wszystkich więzieniach we Włoszech. Działalność centrów nastawiona jest głównie na obcokrajowców oraz młodocianych. Około 4,2 miliona dorosłych (20-64) ma najwyżej ukończone szkoły elementarne. W 2009 roku jedynie pięćset tysięcy młodych dorosłych (20-34 lata) miała wykształcenie elementarne.

W 2009 roku powstały CPIA - Centri Provinciali per L'Istruzione degli Adulti - Prowincjonalne Centra Edukacji Dorosłych. Działały przy szkołach zawodowych i prowadziły kursy wieczorowe. Uczestnicy to głównie młodzi dorośli pracujący. Wykładowcy na tych kursach mają kwalifikacje kształcenia dorosłych. System kształcenia jest źle finansowany i zorganizowany. Brakuje dobrze przygotowanej kadry. Występuje wiele działań okazjonal- 
nych, krótkowzrocznych, konieczne jest regularne działanie różnych form edukacji adresowanych do zróżnicowanych grup wieku i sytuacji społeczno-kulturalnej. Tak jest w przypadku UTW, centrów, bibliotek i stowarzyszeń społecznych, które się ustabilizowały i działają dość regularnie.

Wysiłki budowy systemu edukacji dorosłych opierają się na zasadzie podstawą działania jest jednostka z jej problemami, potrzebami, oczekiwaniami i zainteresowaniami. Badania nad edukacją ujawniają rolę grup skupiających jednostki o podobnych zainteresowaniach, potrzebach i umiejętnościach. Owe grupy stają się bazą dla opracowania projektów działań edukacyjnych i programów pracy. Ważną rolę w organizacji instytucji edukacyjnych odgrywają ośrodki regionalne, samorządy lokalne, stowarzyszenia społeczne i jednostkowe siły społeczne. Trzeba także czerpać wskazówki z różnych źródeł z poziomu centralnego, przez poziom kraju i międzynarodowych ekspertów. Konieczne jest przedstawienie tematów i form kształcenia, uwzględniających zainteresowania i możliwości czasowe dorosłego. Sposób działania, ocena, dyplomy i uprawienia muszą brać pod uwagę odrębność i swoistość edukacji dorosłych.

W edukacji uczestniczą różne podmioty: Ministerstwo edukacji, Polityka społeczna, Samorządy lokalne. Konieczne jest uwzględnienie słabych grup, z marginesu społecznego, stygmatyzowanych biedą, nałogami, przestępczością. Między instytucjami często brak współpracy i współdziałania, nie są skoordynowane działania lokalne, regionalne i centralne, wydatki oraz sposób finansowania. Można więc opracować pewne zalecenia.

Oto one:

- Edukacja na poziomie podstawowym i średnim powinna być finansowana przez Ministerstwo Edukacji. Edukacja na wyższym poziomie i kształcenie zawodowe, obok pieniędzy z ministerstwa, powinna być dofinansowana przez gminy, stowarzyszenia społeczne i różne działania prywatne. Rozwój kulturalny powinien być finansowany przez region i stowarzyszenia społeczne.

Powrót do tradycyjnych form edukacji dorosłych, do centrów i bibliotek jest zadziwiające. Szczególnie, że ujawniło się po Międzynarodowej Konferencji Oświaty Dorosłych w 1997 roku. Powtórzmy - w 1997 roku, prawem 455 powołano Centri Territoriali Permanente - jako realizacja prawa do wiedzy. Dodajmy, że UTW także organizowane są przez gminy, przez regiony, obok stowarzyszeń społecznych. Włochy są przykładem jak wolno mielą młyny edukacji. Jak trudno jest przejść społeczeństwu z poziomu analfabetyzmu do poziomu wykształcenia pełnego, obligatoryjnego w państwie, jak trudno czerpać korzyści z E-edukacji oraz jak mozolny jest proces integracji 
imigrantów z południa na północ i obcokrajowców osiadłych we Włoszech. Jak niski jest procent uczących się dorosłych Włochów w stosunku do Europy, szczególnie Krajów Skandynawskich. Zdumiewa rozwój UTW w całych Włoszech, ich wrastanie w środowisko i popularność. Choć korzystają z nich osoby o wyższym poziomie wykształcenia, to ich aktywność w ruchu wolontariatu na rzecz UTW jest godna podkreślenia.

Zwiedzając Włochy spotyka się ludzi grzecznych, z oddaniem wykonujących swój zawód - sprzedawcy, kelnera, urzędnika, kierowcy, hotelarza itp. Bogactwo zabytków i dzieł sztuki w każdym zakątku kraju potwierdza przekonanie, że życie jest procentem edukacji, że edukacja dokonuje się przez życie.

Specjaliści zajmujący się włoską edukacją dorosłych wiedzą jak przedstawić i wprowadzić ją w sposób ciekawy i wielostronny.. Potrafili wprowadzić ją w obieg europejskiej dyscypliny i zaistnieć w świecie. Takimi osobami byli E. Gelpi, A. Lorenzetto, a jest D. Demetrio, L. Formenti.

\section{Biblioteka w kształceniu dorosłych}

Biblioteka powinna być instytucją służącą społeczności lokalnej, dlatego trzeba tworzyć biblioteki w gminach zamieszkałych przez 2 do 10 tysięcy mieszkańców i w peryferyjnych dzielnicach dużych miast. Biblioteka może stać się ośrodkiem edukacji dorosłych, kontaktu z nowymi technikami informatycznymi, miejscem integracji i socjalizacji.

Badania stanu czytelnictwa we Włoszech określiły, że 45,1\% Włochów deklaruje, że czyta jedną książkę w trakcie roku. Jeden Włoch na dwóch czyta dziennik. Co druga osoba nie czyta gazet. 91,4\% ogląda telewizję, 38,3\% korzysta z Internetu. Są to w większości młodzi ludzie, którzy częściej korzystają z Internetu niż z książek ucząc się w szkole. Szkoły nie wykorzystują Internetu. Nauczyciele są przeważnie osobami w wieku 50 lat i nie są pokoleniem informatycznym. Choć Włosi chętnie chodzą do muzeum, do opery i do kina, a biblioteka postrzegana jest jako ważna instytucja edukacyjna, to raczej można mówić o wiodącej roli telewizji, która posiada kilka kanałów centralnych i rozwiniętej sieci stacji telewizyjnych lokalnych. Jest popularnym i najczęstszym sposobem spędzania czasu wolnego, choć funkcjonują różne zespoły amatorskie jak chóry, zespoły muzyczne, sportowe, koła łowieckie. Czas wolny spędza się także w restauracji, w pizzerii czy barze.

Informacje dotyczące polityki przekazywane są głównie przez telewizję. Audycje to ogląda 93\% telewidzów, 50\% ogląda telewizję lokalną, 31\% 


\section{Olga Czerniawska}

słucha radia, $25 \%$ rozmawia o polityce ze znajomymi, $19 \% \mathrm{z}$ kolegami w pracy, a $15 \%$ czyta dzienniki i magazyny, $2 \%$ należy do partii politycznych i tyleż do związków zawodowych. Polityką nie interesują się młodzi ludzie, zainteresowanie nią rośnie $z$ wiekiem - najwyższe jest $\mathrm{w}$ grupie 60-64 lata wśród mężczyzn. W ostatnich latach zainteresowanie polityką wzrosło, ale przejawia się tylko w świecie osób oglądających programy telewizyjne polityczne. W XXI wieku zaobserwowano wzrost aktywności rekreacyjnej i wolontariatu.

Kryzys, jaki przeżywają obecnie biblioteki i czytelnictwo, nie powinien powodować się z promowania tych instytucji przez system oświaty dorosłych. Biblioteki odgrywają ważną rolę w Wielkiej Brytanii. Występują w systemie instytucji wspieranych przez UNESCO; świadczy o tym Federacja Stowarzyszeń Bibliotek i Bibliotekarzy IFLA International Federation of Library Association and Institution.

Biblioteka oferuje pomoc w rozwoju, jest miejscem dostępu do wiedzy. Nawet w sytuacji technik informatycznych służy dorosłym w formowaniu się ich procesu rozwoju i uczenia się. Nie jest konkurencją dla E-edukacji, przeciwnie, sprzyja jej. Biblioteka publiczna i jej różne rodzaje - parafialne, szpitalne, szkolne, uniwersyteckie, stowarzyszeń społecznych stanowią ważną instytucję w procesie kształcenia ustawicznego, samokształcenia, kształcenia zawodowego itp. W bibliotece upatruje się ważne ogniwo kształcenia na odległość z możliwością poradnictwa, udostępnienia materiałów i programów, organizowania kursów i spotkań.

Ciekawe zajęcia prowadzone są w Bibliotece di Olgiate Comasco należącej do systemu Overt Como do którego należą trzydzieści dwie małe i średnie gminy. Prowadzone są w nich kursy internetowe, cztery spotkania po dwie godziny każda, dla uczestników E-Uniwersytetu dla dorosłych. Doradza się jak studiować na odległość, jak korzystać z różnych form przekazu wiedzy. Uruchomiony został katalog elektroniczny.

Biblioteca di Vimercate działa od 1993 roku, posiada katalog elektroniczny. Od 2000 roku za opłatą biblioteka prowadzi kursy. Proponują tutaj kursy uczące, jak korzystać z biblioteki wirtualnej. Są one prowadzone w małych grupach do ośmiu osób w zakresie technik informatycznych. Uczestnicy to osoby od 40 do 60 lat.

Ciekawe zajęcia proponuje Biblioteca Lazzerini di Prato dla obcokrajowców: Chińczyków, Arabów, Pakistańczyków, Albańczyków. Uczy języka, prowadzi zajęcia międzykulturalne. 


\section{Kursy i e-edukacja}

Nowym zjawiskiem jest uczestniczenie w zajęciach na wyższych uczelniach. Choć cykle wykładów w ramach prawa 150 godzin odbywały się od lat siedemdziesiątych, to regularne uczestniczenie w zajęciach, w charakterze studenta, dorosłej pracującej osoby, w tym najczęściej kobiety, zmieniło atmosferę wyższej uczelni.

Dorośli studenci uczestniczą w różnych formach studiów. W kursach doskonalących ich w zawodzie, w kursach: „odświeżających” wiedzę, aktualizujących wiedzę, uzupełniających wykształcenie. Mogą korzystać z kredytów i opracować swój program zajęć i zdobywać odpowiednią liczbę punktów. Mogą korzystać z tradycyjnego toku studiów lub formy E-learning.

$\mathrm{Na}$ dwóch tysiącach kursów studiuje sześćdziesiąt tysięcy osób, średnio trzysta osób na kursie. Na dwunastu uniwersytetach: Ancona, Bolzano, Calabre, Catania, Chieti-Pescare, Genova, Milano-Cantalice, Roma Tor Vergate, Roma Tre, Roma Lumsa, Udine działa EUCEN - Europejski Uniwersytet Edukacji na Odległość. W systemie tym opracowuje się formy kształcenia na odległość, jakość kształcenia, poradnictwo i pomoc (www.eucen.org). Ze studiów mogą korzystać Włosi pracujący za granicą, chorzy, osoby o specjalnych uzdolnieniach, ale także słabe, wykluczone społecznie. Jest to nowa technologia i dydaktycznie forma $\mathrm{z}$ nowymi profesjami tutora. Ten system studiowania reguluje dekret 5091999 art. 5.

Wkroczenie na uniwersytety dorosłych i wzbogacenie środowiska akademickiego o element studenta pracującego, głównie kobiety, która jest gospodynią domową, żoną i matką oraz dobrze radzącą sobie studentką przyniosło zadowolenie. Jednocześnie pojawiła się obawa przed obniżeniem poziomu studiów i roli dyplomu. Włosi boją się tzw. śmieciowych dyplomów, mało cenionych i nisko opłacanych przez pracodawców.

Pojawiły się nowe oferty studiów wyższych, w tym Uniwersytet w Anghiari (2007, Czerniawska), kształcący w zakresie dydaktyki biograficznej.

\section{Centri Interculturali}

W 1999 roku odbyła się następna konferencja w Wenecji. Owocem owych konferencji było:

1) Powstanie mapy Centrów Interkulturalnych.

2) Charakterystyka ich działalności, model Centrum, spis działów.

3) Przedstawienie Centrum w małym i dużym mieście. 


\section{Olga Czerniawska}

Opis ośrodków.

Udział Centrów w opracowaniu informacji i dokumentacji, przedstawienie współpracy Centrów z władzami lokalnymi, stowarzyszeniami i rodzinami emigrantów. Tworzenie ekip interkulturalnych.

Starano się określić funkcję Centrum, rolę edukacyjną, integracyjną, głównym celem jest pomoc w procesie integracji stawania się obywatelem.

Zbierano doświadczenia Centrów. Ogółem działało ich czterdzieści, w tym trzy działały w Bolonii i Mediolanie, dwa we Florencji i Padwie, Rzymie, Trydencie, Turynie, w Udine. Najczęściej organizatorami Centrum są gminy, następnie władze oświatowe, urzędy opieki społecznej, kultury, rzadziej sami imigranci. Ekipy Centrów to wolontariusze, pracownicy socjalni i urzędnicy.

Większość centrów działa w godzinach 17.00-22.00. Kilka jest otwartych od rana do wieczora. Działania obejmują kształcenie głównie języka włoskiego. Prowadzi się też zajęcia dla dzieci i młodzieży, reedukację oraz rehabilitację osób niesprawnych. Opieką objęte są także dzieci, które urodziły się we Włoszech, ale mówią słabo po włosku. Działalność centrów obejmuje edukację, poradnictwo, opiekę i wsparcie. Prowadzone są seminaria, wydawnictwa, badania uczestników. Centra walczą z wykluczeniem i dezintegracją społeczną, z marginalizacją. Na bazie pracy Centrów formują się nowe profesje - mediator pracy z cudzoziemcami. Pozwoliło na to dziesięcioletnie doświadczenie pracy niektórych Centrów, które powstały w latach 80-tych i spowodowały powstanie prawa 401989 .

We Włoszech - jak starałam się to przedstawić w moich artykułach (Czerniawska, 1997), w edukacji dorosłych preferuje się intensywną pracę z małą grupą, wykorzystuje się założenia pedagogiki P. Freire, który dążył do konscjentyzacji, rozbudzania świadomości. Konscjentyzacja jest podstawą edukacji, dlatego poszukuje się podstaw pracy z emigrantami w badaniach ich mentalności, potrzeb, opinii ich świata. Służyły temu między innymi badania uczestniczące, w których imigranci z Afryki Północnej, Algierii, Egiptu, Ameryki Łacińskiej, Peru, Kolumbii, Dominikany - piętnaście osób w wieku 26-45 lat, mieszkających we Włoszech od siedmiu do dziesięciu lat, reprezentujących różny poziom doświadczenia - analizowało problem, czym jest dorosłość w różnych kulturach, co to znaczy być dorosłym (Castilgioni, 2000, s. 141-151). Zajęcia rozpoczynały się przedstawieniem problemu wieku i dorosłości we Włoszech, w kulturze europejskiej, następnie założeń prezentacji autobiografii. Część drugą, autobiograficzną, rozpoczęły dwie osoby, jedna pochodziła z Kamerunu, druga z Ameryki Łacińskiej. Następnie piętnastu uczestników seminarium przedstawiło swoje wizje dorosłości. 
W analizie problemów dorosłości uwzględniono role społeczne, wydarzenia, wpływ warunków społecznych, sposoby osiągnięcia dorosłości, inicjacji, rytuały, przemiany w tożsamości bycia dorosłym. Przyjmowano zawsze perspektywę autobiograficzną. Zastanawiano się nad wskaźnikami bycia dorosłym i wyznacznikami bycia bardziej lub mniej dorosłym.

Dorosłość w społecznym aspekcie to według wypowiedzi imigrantów poczucie autonomii, świadomość i wiedza o samym sobie, umiejętność wyboru. Dorosły to ten, który własnymi siłami umie wybierać, postanawiać i decydować, umie rozwiązywać codzienne problemy, które stawia przed nim życie. Dorosły potrafi określić swoje kompetencje, możliwości i umiejętności. Co będzie mógł zrobić, a czego nie zdoła. Sam dokonuje wyboru i podejmuje decyzje.

Imigranci z Kamerunu, Maroka i Kolumbii mówili, że dorosły nie może zmienić swoich wyborów. Powinien wywiązać się z roli pracownika, męża, żony, emigranta - mieszkańca danego kraju. Dorosły powinien respektować pewien porządek ról społecznych, małżeństwo, rodzicielstwo, pracę. Przestrzeganie owego porządku występowało we wszystkich kręgach kulturowych. Emigrantka z Peru mówiła, że dorosłym nie wybacza się wyboru stylu życia, zabawy, życia dla rozrywek. Jeśli ktoś studiuje i przerywa studia na podróż, to jest to źle widziane.

Dorosłość to role pracownika i rodzinne. Role rodzinne są bardzo ważne. I nie powinno się ich zaniedbywać na rzecz pracy, stwierdza inna emigrantka z Peru. Podobne opinie wypowiada Kolumbijka i Marokanka. Role społeczne kształtowane są przez religię. Tak jest w odniesieniu do islamu. Islam inaczej postrzega role męskie i kobiece - kobieta jest przeznaczona do ról rodzinnych, dla domu, wychowywania dzieci. Odrębność ról społecznych kobiet i mężczyzn przedstawiają także emigranci z innych regionów - z Filipin, Somalii, Dominikany. Osiąganie dorosłości nie jest związane z jakimś wiekiem, ale $\mathrm{z}$ wydarzeniami, takimi jak małżeństwo, rodzicielstwo, praca zawodowa. Jednak w niektórych regionach dorosłość zaczyna się od dojrzałości seksualnej i towarzyszy temu pewien rytuał. Tak jak na Filipinach. Kiedy dziewczyna ma pierwszą miesiączkę, przechodzi przez rytuał oczyszczenia, staje się dojrzała do ról rodzicielskich. W Ameryce Łacińskiej dorosłość rozpoczyna się, gdy dziewczyna kończy 17 lat, a chłopiec 18 lat (Kolumbia), lub gdy kończą 18 lat (Peru). Tak więc obok ról społecznych, miarą dojrzałości jest dojrzałość biologiczna, a w niektórych kulturach wiek kalendarzowy.

Model dorosłości zawarty w kulturach krajów pochodzenia obejmuje role społeczne inne dla mężczyzn i kobiet, dojrzałość biologiczną, a w niektórych krajach wiek kalendarzowy. Tymczasem we Włoszech normy doro- 
słości są inne, dlatego imigranci przeżywają trudności w przystosowaniu się do nich. Niektórzy przechodzą przez fazę pseudodorosłości i pseudodojrzałości. Korzystanie $z$ niezależności i pewne manowce niezależności wykluczają ich z kręgu własnej kultury. Tracą poczucie tożsamości, żyją tu i tam, przeżywają lęki i poczucie winy wobec wartości i norm krajów, z których pochodzą.

Dorosłość - jak powiedziała Tadune z Somalii - może być porównywana z pociągiem w drodze, który przejeżdża przez różne miejsca, ale ma jeden kierunek, może napotkać różne nieprzewidziane przeszkody i zmieniać drogę. Seminaria, na których realizuje się projekty badań uczestniczących, których rezultaty służą praktyce od lat, stosowane były we włoskiej andragogice (Czerniawska, 1997).

Składa się na to rozbudowany problem pracy z kobietami. Oto jego omówienie.

Program edukacji kobiet postrzega je jako jednostkowe siły społeczne ważne w procesie integracji i życia rodziny oraz rozwoju środowiska lokalnego, dlatego zajęcia mające na celu wprowadzenie kobiet w życie społeczne tzn. korzystanie z instytucji społecznych opieki i pomocy, z urządzeń społecznych jak bank, poczta, ośrodek zdrowia, szkoła dla dzieci, ośrodki opieki itp. W trakcie edukacji wykorzystuje się wiedze kobiet na temat obyczajów, kultury, szczególnie kultury życia, gotowania, szycia, obchodzenia świat itp. W programie edukacji przewidziane są liczne wycieczki i wizyty w urzędach, w sklepach, w urzędzie pracy, organizuje się spotkania, na których kobiety przedstawiają swoje kraje pochodzenia, ich kulturę, obyczaje np. stroje, tańce, pieśni. Program edukacji kobiet zawiera dużo zajęć praktycznych przygotowujących do pracy, życia w włoskim świecie, miasteczku czy na wsi (Czerniawska, 2007).

Drugi przykład to system Centrów Interkulturowych powołanych w oparciu o prawo 40/1998. Są one określane jako miejsca wspólne. Zanim omówię ich działalność, chcę jeszcze przedstawić Centra Sociale Communali Autogestiti (CSOA) nastawione na uczestnictwo młodzieży. Pojawiły się we Włoszech w latach siedemdziesiątych, choć działały już w latach 1965-67. Były tworzone przez samorządy miejskie. Ich działalność miała podstawy pracy socjalnej wspierania młodocianych, bezrobotnych, młodzieży trudnej. Organizowano w Centrach różne zespoły, kursy, życie kulturalne, chóry, zespoły muzyczne, teatralne itp. Był to czas terroryzmu Czerwonych Brygad, trudności ekonomicznych i społecznych. Autonomiczne działania młodzieży. Organizowanie się młodzieży wśród zadań pozytywnych, jak sztuka, nauka, działalność społeczna, były ważne. Dlatego w dużych miastach, a takim 
jest Mediolan, tworzono Centra, czy finansowano ich prowadzenie i działanie. W Centrach działały kursy, realizujące edukację przewidzianą prawem 150 ore, a więc szkoły, kursy zawodowe. Centrami interesowały się ruchy lewicowe, w tym studenckie oraz kultury alternatywnej nastawionej na graffiti. Przywiązanie do instytucji centrów ujawnia rozwój Centrów interkulturalnych Centri Interculturali (Favoro, 2000, s. 212-220). Wzrost liczby imigrantów osiedlających się we Włoszech wywołał potrzebę stworzenia sieci placówek nastawionych na pracę z imigrantami, na naukę języka włoskiego, przekazywanie wiedzy społecznej o instytucjach i prawach obowiązujących we Włoszech, o przywilejach i obowiązkach mieszkańców tego kraju, o kulturze, opiece społecznej i higienie. Centra powstawały w małych ośrodkach, ale także w dużych miastach, jak Mediolan, Rzym, Wenecja itp.

W 1998 roku zorganizowano Konferencję w Mediolanie. Ogółem, dwa, trzy miliardy euro na edukację dorosłych to bardzo mało w porównaniu do innych państw w Europie. Należy stworzyć korzystne warunki osobom, które chcą się uczyć i mają własne projekty edukacyjne. Konieczny jest system stypendiów, ulg i egzaminów, potwierdzających wiedzę i umiejętności poszczególnych osób, które zdobyły w edukacji nieformalnej.

Ważne jest kształcenie dorosłych w zakresie pracy. Grupa o bardzo niskim poziomie wykształcenia, pracujący i pracujący na czarno to pierwsza grupa. Osoby o niskich kwalifikacjach zawodowych. Trzeba także edukować pracowników małych przedsiębiorstw. Tą dziedziną winny zająć się związki zawodowe.

Kolejne grupy to grupy o niskim poziomie kultury, zmarginalizowane społecznie, słabe, to pole dla uniwersytetów powszechnych, stowarzyszeń społecznych, parafii, wolontariatu. Ważne także jest czuwanie nad analfabetami, w tym analfabetyzmem funkcjonalnym.

\section{Zakończenie}

We Włoszech prowadzi się dyskusję nad integracją systemów edukacji dorosłych. Konieczne jest opracowanie programu zintegrowanego, który obejmie różne grupy.

Grupa pierwsza to osoby o wysokim poziomie wykształcenia, dobrze przygotowane do edukacji ustawicznej, w tym przez Internet.

Druga grupa ma niższy poziom wykształcenia i różne trudności, ale jest na tyle samodzielna, że radzi sobie z wyborem ofert edukacyjnych. 


\section{0 | Olga Czerniawska}

Trzecia grupa jest najsłabsza, wymaga wsparcia i pomocy w wyborze ofert edukacyjnych i ich kontynuacji. Edukacja dorosłych obejmuje tzw. grupy priorytetowe. Obok młodocianych, o których już pisałam, są to więźniowie i obcokrajowcy. Centra działają w wszystkich więzieniach i ułatwiają więźniom uzupełnienie wykształcenia i zdobycie kwalifikacji zawodowych.

Imigranci w Europie Zachodniej stanowią ważny problem społeczny. Tak jest i we Włoszech. Opracowano cały program pracy z imigrantami.

\section{Bibliografia}

Appunti Critici Sulla Formazione Continua in Italia (2008), „Enaip Formazione \& Lavoro" N. 3.

Czerniawska O. (1996), Edukacja dorosłych we Włoszech. Wybrane problemy, Łódź.

Czerniawska O. (2007), Nowe drogi andragogiki i gerontologii, Łódź.

Czerniawska O. (2007), Szkice z andragogiki i gerontologii, Łódź, s. 181-195.

Czerniawska O. (2007), Edukacja dorosłych we Włoszech wobec emigrantów, w: A. Fabiś, Myślenice, s. 265-275.

Favoro G., I Centri interculturali in Italia di mediazione e de sambiotra culturale, „Adultita" N. 11, pag. 212-220.

Il lifelong learning e l'educazione degli adulti in Italia e in Europa (2010), "Quadermo" N. 9,.

Rapporto sul Lifelong learning in Italia e sulla formazione al. volontariato comme opportunita di educazione continua, 2004.

Rapporto annuale sulla Formazione continua, 2010.

Życie i uczenie się dla pomyślnej przyszłości. Siła uczenia się dorosłych (2008). UNESCO Contiutea VI, Radom. 